\title{
Homelessness Coverage, Social Reality, and Media Ownership: Comparing a National Newspaper with Two Regional Newspapers in Canada
}

\author{
Mao $\mathbf{Y}^{1}$, Richter $\mathrm{MS}^{2 *}$, Kovacs Burns $\mathrm{K}^{3}$ and Chaw-Kant $\mathrm{J}^{4}$
}

${ }^{1}$ Department of Media and Communication, Erasmus University, Rotterdam

${ }^{2}$ Faculty of Nursing at the University of Alberta, Canada

${ }^{3}$ Health Sciences Council, University of Alberta, Canada

${ }^{4}$ Faculty of Nursing, University of Alberta, Canada

\begin{abstract}
The media plays an important role in the discourse of homelessness. The purpose of this study was to compare how two Alberta newspapers (Calgary Herald and Edmonton Journal) and one national newspaper(the Globe and Mail) covered homeless issues in terms of population, main themes, article type, monthly differences, and critical time periods. Through purposive sampling technique, 449 articles from 1987 to 2007 were selected for analysis, including 128 news articles from the Edmonton Journal, 152 from the Calgary Herald and 169 from the Globe and Mail. A content analysis showed that these newspapers have different agenda settings for homelessness related issues. We argue that the differences among the newspapers' coverage on homelessness are directly related to media ownership, and the unique economic and political structure and ideology at national and provincial levels.
\end{abstract}

Keywords: Homelessness; Newspaper; Media ownership; Agendasetting; Alberta; Canada

\section{Introduction}

Newspapers continue to be a relevant source for news and information across Canada. Over three-quarters (77\% - 14.7 million) of adults in Canada are living in markets where a daily newspaper is available to read, either as a printed or online edition. $73 \%$ of Canadians read at least one newspaper each week, and within that group, $22 \%$ read an online edition in the average week. On the average weekday, $47 \%$ read a printed daily newspaper [1].

In Canada, national newspapers remain a highly influential voice in opinion formation and are a dominant source of information. The media is used as a tool to draw attention to specific issues regarding homelessness, to educate the public, and to put policymakers on the spot by drawing attention to their actions. This study includes a comparison of three Canadian newspapers' coverage of homelessness-related issues. We describe and compare how homelessness issues are covered in two Alberta newspapers, the Calgary Herald and the Edmonton Journal; and one national newspaper, the Globe and Mail.

This study answers Menéndez Alaroón's (2010) call for research to understand how the socio-cultural environment influences national newspapers in comparison to provincial newspapers' reports on social issues, in this case homelessness [2]. This research examines differences and similarities across one national newspaper and two regional newspapers through quantitative content analysis, and then discusses key findings in relation to social ideologies and newspaper ownership. The quantitative and comparative dimensions of newspaper content analysis allow the researchers to demonstrate the dominance of some explanations in news accounts. This is one of the few comparative research studies on Canadian newspapers' coverage of homelessness. The findings of this study can deepen the understanding of how Canadian newspapers set the agenda for homelessness in relation to media ownership and the social reality of homelessness. Journalists can benefit from the study by reflecting on how they set the agenda and why they choose to do so, in order to achieve more ethical journalist practice. Social activists on homelessness can learn from this study by understanding how different types of newspapers portray homelessness, and can choose the right venue to advocate for homelessness-related issues. The general public can be more critical in digesting newspaper coverage on homelessness with the knowledge of how media set the agenda of covering homelessness for different reasons, and by understanding the extent to which newspaper coverage on homelessness reflects the social reality.

\section{Background}

Alberta is one of the three Prairie Provinces in Canada and has a population of approximately 3.4 million people. The economy in Alberta centers on the farming and oil sand industries, and is one of the richest provinces in Canada. There is a belief that this province, with its oil wealth, could become the nation's provincial powerhouse in the years to come. Edmonton and Calgary are the two major cities in the province. Alberta is the first province in Canada to adopt a plan for ending homelessness, with Calgary being the site of the first ten-year plan to end homelessness in Canada [3]. Calgary houses most of the head offices of the oil companies and is described as a white collar city. Edmonton is the capital city of Alberta, and is the political center of the province. Edmonton is situated approximately $300 \mathrm{~km}$ north of Calgary and is a more industrial city. Edmonton is described as the Gateway to the North as all the industrial supplies for the oil field industry are produced and shipped from and through Edmonton. The fast developing Alberta economy has left the province with unanticipated problems such as a struggle to keep up with infrastructure development. A shortage of adequate housing is a challenge and the booming construction industry is struggling to meet demand. It is also important to note that Albertans are the lowest-taxed people in Canada, mostly because of the province's considerable oil and gas income as well as the

${ }^{*}$ Corresponding author: Richter MS, Associate Professor, Faculty of Nursing at the University of Alberta, Canada, E-mail: solina.richter@ualberta.ca

Received May 15, 2012; Accepted June 14, 2012; Published June 16, 2012

Citation: Mao Y, Richter MS, Kovacs Burns K, Chaw-Kant J (2012) Homelessness Coverage, Social Reality, and Media Ownership: Comparing a National Newspaper with Two Regional Newspapers in Canada. J Mass Commun Journalism 2:119. doi:10.4172/2165-7912.1000119

Copyright: (c) 2012 Mao Y, et al. This is an open-access article distributed under the terms of the Creative Commons Attribution License, which permits unrestricted use, distribution, and reproduction in any medium, provided the original author and source are credited. 
more conservative financial philosophies of successive governments. The two main newspapers in Alberta are the Calgary Herald and the Edmonton Journal. The average number of copies sold per publishing day in 2008 was 171,433 for the Calgary Herald and 177,225 for the Edmonton Journal [4].

In comparison to the Edmonton Journal and the Calgary Herald, the Globe and Mail is English, nationally distributed newspaper, based in Toronto and printed in six cities across the country. The Globe and Mail is Canada's largest-circulated national newspaper and second-largest daily newspaper after the Toronto Star. Toronto is one of the largest metropolitan areas in Canada with a population of approximately 2.5 million in 2006 [5]. It is the manufacturing capital and the economic heart of Canada. Toronto has also become the site of many headquarters of companies which need to stay close to the center of finance, but have their primary activities elsewhere, such as mining and real estate. It is home to over 80,000 businesses. The population of Toronto tends to be more liberal politically than the traditional conservative Albertans.

\section{Literature Review}

Homelessness is a worldwide problem and has increased dramatically over the last decade. Several societal factors contribute to the increased rate of homelessness, including lack of affordable housing, decreases in availability of rent subsidies, unemployment, cutbacks in public welfare programs, substance abuse, deinstitutionalization of the mentally ill, and increasing rates of poverty. Some personal circumstances also increase one's risk of homelessness; for instance limited income earned from marginal jobs, and personal crises such as divorce or domestic and family violence. Limitations on the availability of public assistance and a faltering economy have destabilized millions of families and ultimately forced many into homelessness. Homelessness is not simply a housing issue; rather it originates from multiple factors such as poor education, lack of employable skills, inadequate health care, domestic violence, child abuse, foster care, and insufficient child care [6]. Homelessness is an individual as well as a societal problem. The above-mentioned characteristics can influence the public's values and beliefs about the homeless population.

Homelessness in Canada is a social problem and has its roots in changes that occurred in both the economic system and our value system [7]. Values are prescriptive, proscriptive beliefs. Our values can determine how we will act towards certain groups, in this case, the homeless population. Values will impact our own personal decisions and actions in society, and will shape how we want the politicians to act upon social issues surrounding homelessness [8,9]. Van Staden and $\mathrm{Du}$ Toit (1998) accentuate this point by writing: "The dominant value system serves as a background, a frame of reference, against which one makes choices between alternative actions in everyday activities" [10].

Public values about the homeless population are influenced by the media; it is easy to identify certain beliefs and values that are assumed and which points of view are emphasized. The media yields a lot of power in society today [11]. Milio [in 11] summarizes: ...the media has a central role in creating public opinion not only by what they report but also by choosing whether to say anything at all, who is allowed to speak, how much prominence an issue is given and the way the issue is framed. The role of the media becomes very important when this information is available to policy makers or the public through experience or other sources [11].

Politicians are dependent on what their potential voters' specific beliefs and values are. Since voters' beliefs and values are influenced by how the media portray an issue, in this case the homeless population, health and social care workers can use mass media to promote attitudes and sell political viewpoints that can help reduce homelessness. Therefore, the media's interest in homelessness represents "an important source of data that may be useful in understanding broader societal factors influencing this pressing social issue" [12]. Olstead states that "How the popular media use language to represent the social world has much to do with how that world is understood [13]."In a study of four Canadian newspapers' coverage on homelessness from August 1, 2007 to July 31, 2008, Schneider et al. (2010) finds that experts dominate the public discourse on homelessness while the voice from people who experience homelessness was marginalized. The homelessness population was represented as people that need to be controlled and regulated in order to maintain social order [3]. In a similar vein, by analyzing 61 news pictures on homelessness and volunteerism in the Calgary Herald from November 30, 2008 to January 1, 2009, Remillard and Schneider (2010) reported that individual agency and dignity of homeless people was reduced and the need for more serious and systematic social change was silenced in those images [14].

Glanz, Rimer and Lewis (2002) go further by saying: "The definitions of a social problem is crucial to how the public understands it, the actions individuals or communities are likely to take to ameliorate it, the attention given the problem by different groups, and the knowledge they acquire [15]." It is therefore important that we do know how the media portray homelessness; it will help us understand why the public act or choose not to react.

This study is informed by agenda-setting theory. McCombs and Shaw (1993) stated: "Agenda setting is considerably more than the classical assertion that the news tells us what to think about. The news also tells us how to think about it. Both the selection of objects for attention and the selection of frames for thinking about these objects are powerful agenda-setting roles [16]."

Soroka argues that agenda-setting is the only exploratory structure capable of incorporating mass media studies, public opinion research, and public policy analysis into a single framework.Mass media are powerful in setting different agendas for society, which is a complex process and involves influences from different parties. Journalists usually try to balance their own political beliefs and ways to report the social reality as it is. Media ownership more or less influences journalists" decisions on what to report and how to report. Different media position themselves differently in society; therefore they may set different agendas from their own perspectives [17]. It is important to understand how the media sets its agenda on social issues such homelessness, but little research has been done to compare national newspapers' and local newspapers' coverage on homelessness in Canada. This study is the first attempt to analyze Canadian newspapers' coverage on homelessness with longitudinal data of a 20 -year span. The different levels of comparison between the national level and provincial level, and between newspapers in two cities in the province of Alberta, gives in-depth insights on how different types of newspapers set the public agenda on homelessness within their own social and political contexts. In particular, a comparison was made between the newspapers coverage and the social reality, which provides critical analysis of the agenda setting of homelessness in the selected Canadian newspapers.

\section{Research Questions}

Our study focuses on the time period of 1987 to 2007. The first question focuses on analyzing how the two selected regional newspapers cover homelessness in content and format. The second 
Citation: Mao Y, Richter MS, Kovacs Burns K, Chaw-Kant J (2012) Homelessness Coverage, Social Reality, and Media Ownership: Comparing a National Newspaper with Two Regional Newspapers in Canada. J Mass Commun Journalism 2:119. doi:10.4172/2165-7912.1000119

Page 3 of 7

question is about the comparison between the two local newspapers: the Calgary Herald and the Edmonton Journal. Finally, the third question compares coverage on homelessness in a national newspaper and regional newspapers.

Research question 1: From 1987 to 2007, how did two Alberta newspapers, the Calgary Herald and the Edmonton Journal, cover homeless issues such as population, article type, monthly differences, and critical time periods?

Research question 2: From 1987 to 2007, how did the Calgary Herald and the Edmonton Journal differ in their coverage on homelessness?

Research question 3: From 1987 to 2007, what are the differences between the two Albertan papers and the one national paper, the Globe and Mail, on how they cover homelessness issues?

\section{Method}

\section{Sample}

Purposive sampling technique was used to obtain articles from the three chosen newspapers: The Calgary Herald, The Edmonton Journal, and The Globe and Mail. The inclusion criteria for these newspapers were as below:

- Daily circulation rates must be higher than 100,000 on an average day as per the Canadian Newspaper Association, Daily Newspaper Circulation Report 2006; and

- Newspaper must be available online from 1987 to 2007.

The Globe and Mail has national readership. Two newspapers were chosen from Alberta as it was an Alberta based study. An electronic search of the chosen newspapers over the last 20 years (1987-2007) was performed. We decided to start the search in 1987as newspaper articles on homeless people and homelessness started to peak in the late 1980's. To obtain longitudinal data that show possible differences in the pattern associated with change in economics and political systems over time, we decided to conduct a 20 year study. The words, homeless, homelessness, vagrant, vagrancy, squatters, informal settlements, street children were used as search terms. A $10 \%$ sample of all articles that included the search words was obtained and rated for inclusion.

A modified rating scale adapted from Buck, Toro and Ramos (2004) was used to rate articles [12]. The articles were rated on a 4 point scale: $1=$ low intensity/little relevance, $2=$ moderate intensity/ some relevance, $3=$ high intensity/theme and $4=$ very high intensity/major theme. All articles rated 3 or 4 were included. One team member rated each article and two other investigators independently rated a subset $(20 \%)$ of the same articles for inclusion. Discrepancies were resolved by consensus. The criteria used to decide to include ( $3=$ high intensity/ theme and $4=$ very high intensity/major theme) or exclude (1= low intensity/little relevance, 2 = moderate intensity/ some relevance) were based on the degree of relevance to homelessness and politics (e.g. priorities of the government), homelessness and economics (e.g. charities, government funding practices, economic boom or down turn, loss of jobs), homelessness and environmental factors (e.g. NIMBY- not in my back yard), and homelessness and values (e.g. the public's values, political values).In total 449 articles were selected and analyzed in this study, including 128 news articles in the Edmonton Journal, 152 news articles in the Calgary Herald, and 169 in the Globe and Mail.

\section{Coding system}

Content analysis was performed on the articles. Content analysis

\begin{tabular}{|l|l|l|l|l|}
\hline Themes & $\begin{array}{l}\text { Alberta } \\
\text { newspaper } \\
\text { article number }\end{array}$ & $\begin{array}{l}\text { Globe and Mail } \\
\text { article number }\end{array}$ & $\begin{array}{l}\text { Alberta } \\
\text { newspaper } \\
\text { percentage of } \\
\text { the total }\end{array}$ & $\begin{array}{l}\text { Globe } \\
\text { and Mail } \\
\text { percentage } \\
\text { of the total }\end{array}$ \\
\hline Housing related & 111 & 35 & $39.6 \%$ & $20.7 \%$ \\
\hline $\begin{array}{l}\text { Community aid } \\
\text { and support }\end{array}$ & 60 & 33 & $21.4 \%$ & $19.5 \%$ \\
\hline $\begin{array}{l}\text { Profiling of } \\
\text { homelessness or } \\
\text { homeless people }\end{array}$ & 43 & 32 & $15.4 \%$ & $18.9 \%$ \\
\hline Economic factors & 41 & 45 & $14.6 \%$ & $26.6 \%$ \\
\hline Illegal activity & 18 & 9 & $6.4 \%$ & $5.3 \%$ \\
\hline Health related & 5 & 8 & $1.8 \%$ & $4.7 \%$ \\
\hline Other & 2 & 5 & $.7 \%$ & $3 \%$ \\
\hline Total & 280 & 169 & $100 \%$ & $100 \%$ \\
\hline
\end{tabular}

Table 1: Descriptive Statistics for Themes Covered in Selected Newspapers.

specifically focuses on who says what to whom, how, and with what effect [18]. We used an extraction tool developed by the researchers in a pilot media analysis study that focused on the same two newspapers in Alberta for a 5 year period [19]. During this study, three researchers were asked to independently read 30 articles containing the search words. They had to come up with a coding scheme related to our research question. Each of the three researchers came up with an independently developed coding scheme; it was then compared, combined, discussed and revised to finalize the coding scheme. After the coding frame was developed, it was tested and adapted by two independent coders for content validity. The development was also informed by a guide "Analyzing Newspaper Content, A How-to Guide" [20].

This previously developed coding scheme was again piloted with a small number of articles for a larger study analyzing six major Canadian newspapers' coverage on homelessness from 1987 to 2007 [21]. No changes were made. Variables that were collected included: newspaper name, date of publication, page number it was published on, word count, type of article, gender of the journalist/author, and population identifiers in the article.

The following main contents of the articles were also coded in this study: housing related issues, profiling of homelessness, health related issues, economic factors, illegal activities, community aid and support and social factors as cause of homelessness. Each main theme includes a range of sub themes (Table 2).

\section{Inter-rater reliability}

The inter-rater reliability was tested in the larger study on 6 newspapers' coverage on homelessness in Canada [21]. As this study analyzed a subset of the large database of the above study, the interrater reliability was not tested again. In the larger study, three reviewers analyzed $117(12 \%)$ articles of the sample to test the inter-rater reliability of the main themes. The average kappa value was 0.86 , which shows high inter-rater reliability. Other items in the coding sheet do not involve as much interpretation as the themes, and the kappa value for inter-rater reliability of those "direct information" items was all above 0.9. Overall, the coding system has a high inter-rater reliability.

\section{Results}

\section{Two Alberta newspaper's coverage on homeless issues}

As we discussed in the methods section, the Edmonton Journal and the Calgary Herald are the two newspapers that we selected to represent 
Citation: Mao Y, Richter MS, Kovacs Burns K, Chaw-Kant J (2012) Homelessness Coverage, Social Reality, and Media Ownership: Comparing a National Newspaper with Two Regional Newspapers in Canada. J Mass Commun Journalism 2:119. doi:10.4172/2165-7912.1000119

Page 4 of 7

\begin{tabular}{|c|c|}
\hline Main theme & Sub themes \\
\hline $\begin{array}{l}\text { Housing related } \\
\text { issues }\end{array}$ & $\begin{array}{l}\text { Emergency shelters, } \\
\text { Neighbourhood complaints/protests/Not-In-My-Back-Yard } \\
\text { or NIMBY, } \\
\text { Tent cities, river valley camps, eviction from city parkland, } \\
\text { Weather related issues (cold or heat spell), seeking } \\
\text { shelter (church, parkade, train station etc.), and } \\
\text { Affordable housing needs }\end{array}$ \\
\hline $\begin{array}{l}\text { Profiling of homeless- } \\
\text { ness or homeless } \\
\text { people }\end{array}$ & $\begin{array}{l}\text { Second generation homeless, } \\
\text { Profiling character traits of homeless (e.g. dirty, scruffy, } \\
\text { smelly), } \\
\text { Discrimination, } \\
\text { Rights of homeless persons, } \\
\text { Special needs/disabled (e.g. mental, physical handi- } \\
\text { capped), } \\
\text { Writers' or publics' views and values, statistics, and } \\
\text { Homeless counts }\end{array}$ \\
\hline Health related issues & $\begin{array}{l}\text { Mental illness, } \\
\text { Alcoholism, } \\
\text { Drug abuse, } \\
\text { Access to care/health access, } \\
\text { Susceptible to disease/lack of hygiene/sanitation }\end{array}$ \\
\hline Economic factors & $\begin{array}{l}\text { Government cutbacks, } \\
\text { Government spending/aid, and } \\
\text { Economic factors as cause (e.g. minimum wage, eco- } \\
\text { nomic boom, and jobs); }\end{array}$ \\
\hline Main theme & Sub themes \\
\hline Illegal activity & $\begin{array}{l}\text { Begging/panhandling, } \\
\text { Bottle picking/garbage dumpster diving, } \\
\text { Illegal activity/crime related, } \\
\text { Vandalism, and } \\
\text { Victims of crime/abuse/child abuse in past }\end{array}$ \\
\hline $\begin{array}{l}\text { Community aid and } \\
\text { support }\end{array}$ & $\begin{array}{l}\text { Food and clothing, } \\
\text { Support programs, } \\
\text { Charity, purely giving and receiving, } \\
\text { Donation, fundraising/actions/campaigning/ awareness, } \\
\text { Social factors as cause included family break up and } \\
\text { lack of support from friends and relatives }\end{array}$ \\
\hline
\end{tabular}

Table 2: Content of the newspaper articles: Main and sub themes.

major newspapers' coverage on homeless-related issues in Alberta. Among the total sample of 280 news articles, 50 articles were published in 2007 , which is much more than the number of articles published in any other year from 1988 to 2007. Each of the following year's had 20 to 23 news articles on homeless issues: 1998, 1999, 2000, 2003, and 2006. The years of $1994,1995,1996,2002,2004$, and 2005each had 10 to 15 news articles. Less than 10 articles were found in each of the other selected years. Winter months (January, October, November, and December) had more coverage of homeless issues than other months in the selected articles.

Among the 280 Alberta newspaper articles, most of them are about homeless issues in urban areas $(\mathrm{N}=250,89.3 \%)$, and only a few focus on rural areas $(\mathrm{N}=30,10.7 \%)$. Almost all the news articles $(\mathrm{N}=265$, 94.6\%) are about homelessness in Canada, and very few pay attention to international homeless issues $(\mathrm{N}=15,5.4 \%)$. In terms of types of news articles, around half $(\mathrm{N}=147,52.5 \%)$ are written by journalists, and $38(13.6 \%)$ articles are letters to the editors. Reviews, interviews, community news/events, columns, and editorials each have less than 20 news articles. A similar number of the articles are written by females $(\mathrm{N}$ $=89,31.80 \%)$ and males $(\mathrm{N}=95,33.9 \%)$, and the gender of the other articles' writers cannot be identified. Most of the news articles $(\mathrm{N}=202$, $72.1 \%$ ) cover the general homeless population, and a small number of news articles cover populations such as homeless men $(\mathrm{N}=20,7.1 \%)$, street youth $(\mathrm{N}=18,6.4 \%)$, homeless mentally ill $(\mathrm{N}=10,3.6 \%)$, single parent with children $(\mathrm{N}=8,2.9 \%)$, seniors $(\mathrm{N}=5,1.8 \%)$, families $(\mathrm{N}=$ $5,1.8 \%)$, homeless women $(\mathrm{N}=5,1.8 \%)$, and minorities $(\mathrm{N}=3,1.1 \%)$. Distributions of the different themes of the articles are listed in Table 1.

\section{Comparison between Edmonton Journal and Calgary Herald}

As the two major cities in the province of Alberta, Edmonton and Calgary are similar in many factors that might influence news media coverage on homeless issues. However, some differences are found between these two newspapers on their coverage on homelessness.

First, the Edmonton Journal and the Calgary Herald differ in the type of news articles they have on homeless issues: $\mathrm{X}^{2}=22.4, \mathrm{df}=7$, $\mathrm{p}<.05$. Specifically, with an adjusted residual greater than 2.00 , in comparing the observed frequencies with the expected frequencies, the Edmonton Journal published more news written by journalists $(\mathrm{R}=$ $2.8)$ and reviews $(\mathrm{R}=2.2)$ than expected, while the Calgary Herald $(\mathrm{R}=$ -2.8 for news written by journalists, and $\mathrm{R}=-2.2$ for reviews) published less than expected. However, the Calgary Herald $(\mathrm{R}=2.7)$ had more community news/events than expected while the Edmonton Journal ( $R$ $=-2.7)$ had less than expected.

Second, the Edmonton Journal and the Calgary Herald covered homeless populations differently: $\mathrm{X}^{2}=19.6, \mathrm{df}=9, \mathrm{p}<.05$. Specifically, the Edmonton Journal $(\mathrm{R}=2.3)$ had more articles on homeless men than expected while the Calgary Herald $(R=-2.3)$ had less than expected. However, the Edmonton Journal $(\mathrm{R}=-2.2)$ had fewer articles on the general homeless population than expected while the Calgary Herald had more than expected $(\mathrm{R}=2.2)$.

\section{Comparison between Alberta Newspapers and the Globe and Mail}

The data from the Edmonton Journal and the Calgary Herald are combined to represent Alberta newspapers, and were then compared with a national newspaper, the Globe and Mail. Alberta newspapers show a very different picture than the Globe and Mail (Figure 1) does in the numbers of news articles from 1987 to $2007: \mathrm{X}^{2}=86.3$, $\mathrm{df}=20$, $\mathrm{p}<.05$. Specifically, Alberta newspapers had fewer articles on homeless issues than expected while the Globe and Mail had more than expected in $1987(\mathrm{R}= \pm 4.9)$ and $1988(\mathrm{R}= \pm 3.2)$. Alberta newspapers had smaller numbers of homeless-related articles than expected while the Globe and Mail had more than expected in $2003(\mathrm{R}= \pm 2.8)$ and 2007 $(\mathrm{R}= \pm 5.8)$.

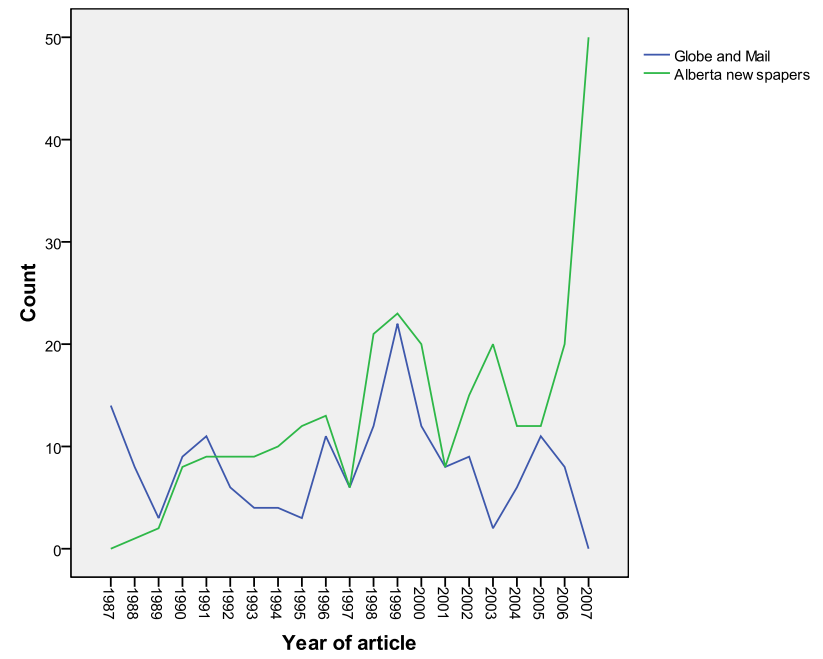

Figure 1: Number of Articles Published in Alberta Newspapers and the Globe and Mail Examined Between 1987 and 2007. 
Alberta newspapers also differ from the Globe and Mail in news article types: $\mathrm{X}^{2}=45.3, \mathrm{df}=7, \mathrm{p}<.05$. Alberta newspapers $(\mathrm{R}=-5.6)$ have less news written by journalists than expected while the Globe and Mail $(\mathrm{R}=5.6)$ has more than expected. Additionally, Alberta newspapers have more editorials $(\mathrm{R}= \pm 2.8)$ and community news/events $(\mathrm{R}= \pm 2.7)$ than expected while the Globe and Mail has fewer than expected.

Differences are also found between how Alberta newspapers cover different themes related to homelessness issues and how the Globe and Mail covers this issue: $\mathrm{X}^{2}=30.6, \mathrm{df}=7, \mathrm{p}<.05$. Alberta newspapers $(\mathrm{R}=4.1)$ have more articles on housing-related issues than expected while the Globe and Mail ( $\mathrm{R}=-4.1)$ has less than expected. Moreover, Alberta newspapers $(\mathrm{R}=-3.1)$ have less articles on economic factors than expected while the Globe and Mail $(\mathrm{R}=3.1)$ has more than expected.

\section{Discussion}

It is well-known that homelessness in Canada has been increasing dramatically over the last two decades. Canada has no national count on homelessness, however in 2007; The Treasury Board of Canada Secretariat estimated that more than 150,000 Canadians were using homeless shelters every year and that countless others are either on the streets or are the "hidden homeless" - away from the public eye and outside of the shelter system [22]. In the province of Alberta, the homeless count has shown increased numbers every year. In Edmonton, the number of homeless people increased from 2,618 in 2006 to 3,079 in 2008; an increase of 8.7\%. If compared with the count in $1999(\mathrm{n}=$ 714 ) it shows an increase of $431 \%$. In Calgary, the number of homeless people also increased by $880 \%$ from the count $1994(\mathrm{n}=461)$ to the count in $2008(n=4060)$. The homeless population in Toronto in 2006 was counted at 5,052 and represented people staying outdoors, in shelters, in health care and treatment facilities, incarcerated in Toronto detention centers and in Violence Against Women shelters [23].

\section{Alberta newspapers}

The results show that in the sample of 280 news articles in the Alberta papers, 50 were published in 2007. In the summer of 2007, there was much media publicity around "tent city," Edmonton's inner city "campground" where many homeless people erected tents as a means of providing a place to call home [24]. The results also relate to specific economic and political activities in the province. It is well-known that in the 2006- 2007 time period, Canada and especially the province of Alberta experienced an economic boom. It contributed to an influx of foreign workers that arrived to work in the oil sand industry; and the related housing shortage, where steep increases in housing prices and rental properties resulted in more homelessness which affected the working poor. The increased news coverage of homelessness in 2007 might also be related to the announcement by the Premier, Ed Stelmach, and the Urban Affairs Minister, that the Alberta government would embark on a 10-year initiative to address homelessness in the province. In 2008, the Government of Alberta established the Alberta Secretariat for Action on Homelessness. The Secretariat was given the mandate to develop a 10-year strategic plan to end homelessness.

Very little attention has been given to homelessness issues in rural areas in the 20 year study period, specifically in Alberta. This is reflected in the little coverage in the two Alberta papers on rural homelessness. The development of the plan to end homelessness in Alberta specifically includes a focus on 7 seven major cities, some of which are classified as rural: Edmonton, Calgary, Fort McMurray, Leth bridge, Red Deer, Grande Prairie and Medicine Hat. It will be worthwhile to do a follow up study for the year 2008 - 2012 to determine if there is an increase in news coverage on homelessness issues in these cities. The homelessness issues in some of the rural cities are different and are often related to a shortage of houses and rental property. A recent environmental scan on homeless related capacities in Alberta concluded that there is a gap in research related to rural, northern and remote communities [25].

The results also show that $13.6 \%$ of the articles are letters to the editor in the Alberta newspapers. It shows a public interest in social issues that affect them specifically. It is important to research if these letters are specifically supportive of opposing homelessness. Alberta, as one of the three Prairie Provinces in Canada, has a long history of a conservative government. For the purpose of this study, we did not specifically look at the tone of the messages. It is also questionable if the tone of letters to the editor will be true reflection of the public's view, as the editor of a journal can choose which "Letters to the Editor" they publish.

Reviews, interviews, community news/events, columns and editorials had less than 20 articles in these two Alberta newspapers for the time periods studied. The format of these types of news articles typically allows for more 'freedom' in expression of opinions on certain issues. It is questionable why the homeless and homelessness are rarely featured in these types of articles. It could possibly be related to the conservative political nature of the Alberta population.

Homeless populations are not homogeneous and the needs of the different subpopulations within this group are very different. The Edmonton Journal had more articles on homeless men than expected while the Calgary Herald had less than expected. However the Edmonton Journal had fewer articles on the general homeless population than expected while the Calgary Herald had more than expected. These numbers do not reflect accurately the homeless count numbers of 2008. The homeless count in 2008 show a homeless population of 4,060 in Calgary and 3,079 in Edmonton. In Calgary 78\% of the homeless people enumerated by facilities and service agencies ( $\mathrm{n}$ $=2491$ ) were observed to be male. In Edmonton's 2008 homeless count $69 \%(n=2124)$ of the homeless people were observed to be male. If we only look at the numbers we would expect more articles in the Calgary Herald that focus on the general homeless population. It is difficult to explain why the coverage differs from the demographics but the findings indicate that the news articles mainly focus on the general homeless population and not the specific subpopulations. The news articles do not indicate the heterogeneity within the homeless populations. A possible explanation is that homeless women are less visible on the streets and more hidden from the public eye, and therefore less reported in the news media [26]. Our findings indicate that a similar number of articles were written by females $(\mathrm{N}=89,31.80 \%)$ and males $(\mathrm{N}=$ 95, 33.9\%). In a previous study conducted by Richter, Kovacs Burns, Mogale, and Chaw-Kant (2011) was found that gender may not have significant impact on what was written about the homeless in the media but gender cannot be ignored as a variable in setting the public agenda or mobilizing public opinions [21].

\section{Comparison between the Alberta papers and the national newspaper}

Alberta newspapers had more articles on housing related issues than expected while the Globe and Mail had less than expected. This can be related to the shortage of housing due to the high number of workers that moved to the oil sands development areas. Alberta newspapers have smaller numbers of homeless articles than expected while the Globe and Mail had more than expected in 2003 and in 2007. 
Citation: Mao Y, Richter MS, Kovacs Burns K, Chaw-Kant J (2012) Homelessness Coverage, Social Reality, and Media Ownership: Comparing a National Newspaper with Two Regional Newspapers in Canada. J Mass Commun Journalism 2:119. doi:10.4172/2165-7912.1000119

Page 6 of 7

This can probably relate to differences in economic development in the different provinces of Canada and the different ownership of the different newspapers. Specific social and political contextual events can be matched with these peaks in newspaper coverage, including the cuts in funding for housing initiatives and social programs in the 1990 's and its impact on housing subsidies and availability, and the shift from the federal to provincial and municipal governments in the mid1990 s resulting in ill-prepared governments being unable to deliver on housing solutions [27-30]. During the 2006- 2007 period Canada and especially the province of Alberta experienced an economic boom with a steep rise in the prices of houses and rental properties resulting in more homelessness including the working poor. This should actually lead to more coverage on homelessness but there was less than expected. It is possible that the news media did not pick up on the effect of the economic boom and the formation of a new category of homeless populations, the working poor.

The Globe and Mail has slightly more news coverage $(n=169)$ on homelessness over the 20 year period than the two Alberta based papers (Edmonton Journal $n=128$ and Calgary Herald $n=152$ ). It is a national newspaper and that can possibly explain why they have more coverage. They are situated in Toronto, which has a larger homeless population than any other Canadian city. The two Alberta papers have more on housing related issues and less on economic factors related to homelessness than the Globe and Mail. These findings could be better understood when we consider the role the newspaper's ownership plays in mass media agenda setting. Newspapers' ownership and their historical context can influence the amount and type or emphasis of coverage of social issues. The corporate form of newspaper organization has raised concerns about the quality and diversity of information shared with the public [31]. It is argued that the "economic imperatives of newspaper operation are incompatible with the goals of free and democratic speech" [31]. Many believe that the corporate form of organizing a newspaper destroys good journalism and endangers democracy. It is also believed that the commercial interests of the corporate newspapers can work to limit the diversity of opinions expressed on certain issues. The Globe and Mail is a Canadian English language nationally distributed newspaper, based in Toronto and printed in six cities across the country. It is Canada's largest-circulation national newspaper and second-largest daily newspaper after the Toronto Star. It is owned by CTV globe media. The Globe and Mail's role in society is seen as independent but not neutral and that could also contribute to the higher amount of coverage of social issues and in this case of homelessness. The other two newspapers in our sample, Edmonton Journal and the Calgary Herald are owned by the Post media network (previously CanWest Global Communications Corporation), a corporate form organization. The two corporate owned newspapers had slightly less coverage of homelessness.

Mass communication plays an important role in our society, and its purpose is to inform the public about current and past events. Within this process the media, and in this case the newspaper media, takes control of the information read through gate keeping and agenda setting. There is ample evidence that editors play an important part in what get published or not. In our study newspaper ownership, the political climate and the visibility or newsworthiness of events related to the homeless population effected if the story got published.

"This impact of the mass media- the ability to effect cognitive change among individuals, to structure their thinking- has been labeled the agenda-setting function of mass communication. Here may lie the most important effect of mass communication, its ability to mentally order and organize our world for us. In short, the mass media may not be successful in telling us what to think, but they are stunningly successful in telling us what to think about [32]."

\section{Conclusion}

This article demonstrates the social and political significance to all media articles, particularly as each part contributes to the overall outcomes. This is demonstrated by our findings that there was more news coverage on homelessness in Alberta during 2007 when specific political decision was made by the premier at that time. Our findings also indicate the differences of how social issues are covered in different newspaper in the same country. We argued that it is related to the difference in the ownership and political atmospheres in the different provinces where the newspapers are located. Our findings indicate the under reporting of different subpopulations in the media. We recommend highlighting the unique needs of the specific subpopulations within the homeless population.

Our study demonstrates the important role of media discourse on the homeless and homelessness. The media can be a strong force in informing the public about a social issue and the potential intervention that will bring about change in the lives of people affected by homelessness.

We argue that what is portrayed in the newspaper articles are directly related to the changes in the economic and political structure of a country or in this case the province of Alberta, Canada. Newspaper ownership also plays a role in what content gets published or not.

\section{Acknowledgements}

This work was carried out with financial support from the Killam Research Fund (Social Science, Humanities, Fine Arts) Cornerstones Grant Program, University of Alberta.

\section{References}

1. Canadian Newspaper Association (2010) Circulation Data Report 2009

2. Menéndez Alaroón AV (2010) Media representation of the European Union: Comparing newspapers coverage in France, Spain, and the United Kingdom. Int J Commun 4: 398-415.

3. Schneider B, Chamberlain K Hodgetts D (2010) Representations of homelessness in four Canadian newspapers: Regulation, control and social order. J Sociol Soc Welf 37:147-172.

4. Alberta, Canadian Politics on line (n.d.)

5. City of Toronto Statistics (2012)

6. Da Costa Nunez R, Caruso LM (2003) Are shelters the answer to family homelessness? USA Today: 46- 48

7. Stewart MJ (2000) Community nursing. Promoting Canadians' health. WB Saunders, Toronto.

8. Allender JA, Spradley BW (2005) Community health nursing. Lippincot Williams \& Williams, Philadelphia.

9. Lundy KS, Janes S (2001) Community health nursing. Caring for the public's health. Jones and Bartlett Publishers, Massachusetts.

10. Van Staden SJ, Du Toit DA (1998) Nursing Sociology. Van Schaik Publishers, Pretoria, South Africa

11. Nutbeam D, Harris E (2004) Theory in a nutshell. A practical guide to health promotion theories. The McGraw-Hill Companies, Sydney.

12. Buck PO, Toro PA, Ramos MA (2004) Media and professional interest in homelessness over 30 years (1974-2003). Anal Soc Issues Public Policy 4: $151-171$.

13. Olstead R (2002) Contesting the text: Canadian media depiction of the conflation of mental illness and criminality. Sociol Health IIIn 24: 621-643. 
Citation: Mao Y, Richter MS, Kovacs Burns K, Chaw-Kant J (2012) Homelessness Coverage, Social Reality, and Media Ownership: Comparing a National Newspaper with Two Regional Newspapers in Canada. J Mass Commun Journalism 2:119. doi:10.4172/2165-7912.1000119

Page 7 of 7

14. Remillard C, Schneider B (2010) Picturing homelessness: visual representations of homelessness and volunteerism in a Canadian newspaper. Soc Dev Issues 32:77-91.

15. Glanz K, Rimmer BK, Lewis FM (2002) Health behaviour and health education. Jossey-Bass, San Francisco.

16. McCombs ME, Shaw DL (1993) The evolution of agenda-setting research: Twenty-five years in the marketplace of ideas. J Commun 43: $58-67$.

17. Soroka SN (2002) Agenda-setting dynamics in Canada. UBC Press, Vancouver

18. Krippendorff K (2004) Content analysis. Sage, Beverly Hills

19. Richter MS, Kovacs Burns K, Chaw-Kant, J (2010) Analysis of newspaper journalists' portrayal of the homeless and homelessness in Alberta, Canada. Int J Child Health Hum Dev 3: 125-136.

20. Lynch S, Peer L (2002) Analyzing newspaper content: A how-to guide, including national comparison data for U.S. daily newspapers. Readership Institute Media Management Center at Northwestern University, Chicago.

21. Richter MS, Kovacs Burns K, Mao Y, Chaw-Kant J, Calder M, Mogale S, Goin L, Schnell K (2011) Canadian media's interest in homelessness: a longitudinal content analysis of homelessness coverage in six major Canadian newspapers from 1987 to 2007. Can J Commun 36: 619-635.

22. The Treasury Board of Canada Secretariat (2012) Retrieved May 11th, 2012 from www.tbs-sct.gc.ca
23. Toronto Shelter, Support \& Housing Administration (2009) Street needs assessment results.

24. Quick K (2008) Health needs of working homeless adults in Edmonton Unpublished Master's degree capping project.

25. Kovacs Burns K, Richter MS (2010) Homelessness-related research capacities in Alberta: A comprehensive environmental scan 1990 - 2010. Retrieved from

26. Richter MS, Chaw-Kant J (2010) Canadian homeless women. Gaps in the research agenda. Int J Child Health Hum Dev 3: 7-15.

27. Bryant T (2004) Housing and health. In Raphael D (Ed.) Social determinants of health: Canadian perspectives. Canadian Scholars' Press, Toronto.

28. Carroll BW, Jones RJE (2000) The road to innovation, convergence or inertia: Devolution of housing policy in Canada. Can Public Policy 26: 277 - 293.

29. Raphael D (2007) Poverty and policy in Canada: implications for health and quality of life. Canadian Scholars' Press Inc., Toronto.

30. Shapcott M (2005) Social (subsidized) housing cures homelessness. Retrieved January 16, 2007 from

31. Harmes D (1999) Corporate news. The issue of newspaper ownership revisited Master's Degree thesis.

32. McCombs ME, Shaw DL (1977) The emergence of American political issues. West Publishing Co., New York. 